\title{
LIBERDADE DE EXPRESSÃO E DIREITO À INFORMAÇÃO NO CONTEXTO DEMOCRÁTICO ATUAL: A DESINFORMAÇÃO NAS REDES SOCIAIS
}

\author{
* Tiago Olympio Spezzatto ${ }^{1}$ \\ ** Daniela Zilio ${ }^{2}$ \\ *** Riva Sobrado de Freitas ${ }^{3}$
}

Resumo: Este trabalho teve por objetivo analisar a liberdade de expressão e o direito à informação em face da desinformação nas redes sociais, com o fito de situá-los e compreendêlos no contexto atual. Para tanto, utilizou-se o método dedutivo, por meio de revisão bibliográfica com enfoque qualitativo. Apresenta-se o seguinte resultado: nas redes sociais, o alcance dos discursos e a circulação de informações são controlados pelas empresas, o que distorce o exercício da liberdade de expressão e o direito à informação, interferindo na construção do debate público democrático.

Palavras-chave: Liberdade de expressão; Direito à informação; Democracia; Redes sociais; Desinformação.

\section{FREEDOM OF SPEECH AND RIGHT TO INFORMATION IN THE CURRENT DEMOCRATIC CONTEXT: THE DESINFORMATION IN SOCIAL MEDIA}

Abstract: This work aimed to analyze freedom of speech and the right to information in the face of misinformation in social networks, with the aim of situating and understanding them in the current context. Therefore, the deductive method was used, through a literature review with a qualitative focus. The following result is presented: in social networks, the reach of discourses and the circulation of information are controlled by companies, which distorts the exercise of freedom of speech and the right to information, interfering in the construction of democratic public debate.

Keywords: Freedom of speech; Right to information; Democracy; Social media; Desinformation.

\section{INTRODUÇÃO}

\footnotetext{
1* Mestrando em Direito pela Universidade do Oeste de Santa Catarina Graduado em Jornalismo pela Universidade Federal de Santa Maria. Graduado em Direito pela Universidade do Oeste de Santa Catarina. Email: tiagospezzatto@gmail.com; Av. Laju 564, Mondaí, Santa Catarina.

2 ** Doutoranda e Mestre em Direito pelo Programa de Pós-graduação em Direito da Universidade do Oeste de Santa Catarina - Unoesc. Especialista em Direito Civil e Direito Processual Civil e especialista no Novo Sistema Processual Civil Brasileiro pela Universidade do Oeste de Santa Catarina - Unoesc. Professora do Curso de Direito da Universidade do Oeste de Santa Catarina - Unoesc, Campus de São Miguel do Oeste e Unidade de Pinhalzinho. Membro do Grupo de Estudos e Pesquisa "Interculturalidade, Identidade de Gênero e Personalidade", vinculado ao Programa de Pós-graduação em Direito da Universidade do Oeste de Santa Catarina. Advogada. E-mail: danielazilio@yahoo.com.br. Chapecó, Santa Catarina.

$3 * * *$ Pós-doutora em Direito pela Universidade de Coimbra; Doutora e Mestre em Direito pela Pontifícia Universidade Católica de São Paulo; Professora e pesquisadora do Programa de Pós-Graduação em Direito da Universidade do Oeste de Santa Catarina (UNOESC - Chapecó/SC). Professora Adjunta Aposentada de Direitos Humanos da Universidade Estadual Paulista “Júlio de Mesquita Filho" (UNESP) - Campus Franca (São Paulo). Chapecó-SC. E-mail: rivafreit@gmail.com.
} 
Os direitos fundamentais de liberdade de expressão e informação estão relacionados, de maneira ambígua, com um dos temas mais complexos e atuais na sociedade: a desinformação.

As alterações no panorama comunicacional trouxeram novas possibilidades para a manifestação do pensamento e para o direito à informação. A ampliação do uso das redes sociais na internet tem provocado diversas mudanças sociais, fazendo surgir novas demandas, sobretudo ligadas ao estudo do Direito. Perquirir os efeitos dessas recentes alterações são elementos de originalidade e novidade do presente trabalho.

A pesquisa tem a seguinte justificativa: a liberdade de expressão e o direito à informação notadamente são pilares dos regimes democráticos. Da mesma maneira, a formação da opinião pública é de extrema relevância, pois é a partir da manifestação de vontade do grupo que devem ser tomadas as decisões que refletem na vida política do Estado. Atualmente, as redes sociais representam significativo papel no debate público.

Revela-se cientificamente importante abordar como as plataformas de redes sociais na internet têm se relacionado com a liberdade de expressão e com o direito à informação, em face da desinformação, uma vez que exercem controle sobre os fluxos comunicacionais nesse importante veículo de construção da opinião pública, interferindo na eficácia horizontal dos direitos fundamentais.

Destarte, a desinformação tem afetado diversos Estados. No Brasil não é diferente. Como evidência disso, a Câmara dos Deputados tem cerca de cinquenta propostas que buscam combater a desinformação. Isso aproxima cada vez mais as redes sociais e a desinformação das ciências jurídicas, seja por facilitar o exercício de direitos, seja pelo potencial de restringi-los.

Expõe-se o problema de pesquisa que norteia o presente trabalho: à luz do debate público nas redes sociais da internet, quais os impactos da desinformação para a liberdade de expressão e para o direito à informação no contexto do Estado democrático? Enfatiza-se que o problema de pesquisa proposto é o desdobramento de uma questão maior: qual a situação e como sobreviverão os direitos fundamentais na internet?

Conseguinte, tem-se como objetivo geral analisar os direitos fundamentais de liberdade de expressão e de informação no contexto do Estado democrático, em face do fenômeno da desinformação nas redes sociais, a fim de situá-los e compreendê-los no 
presente momento, observando-se os aspectos de transformação na comunicação que se processam na sociedade atualmente.

Busca-se verificar as novas possibilidades dos direitos de expressão e de informação no contexto das redes sociais da internet e as recentes demandas que elas trazem ao estudo jurídico. Além disso, são analisados os impactos da desinformação na liberdade de expressão e no direito à informação, bem como suas consequências para a construção do debate público no Estado democrático. Ademais, aborda-se como o potencial de interferência nos fluxos comunicacionais, pelas plataformas e pelos usuários de redes sociais, reflete na eficácia horizontal dos direitos fundamentais de liberdade de expressão e de informação.

Com o fito de perquirir os objetivos propostos, dentro dos limites estabelecidos, tratase de uma pesquisa de revisão bibliográfica, na qual se estabelece um diálogo entre diversos autores e perspectivas científicas, utilizando-se sobretudo de fontes primárias. O principal método utilizado é o dedutivo, partindo-se dos elementos gerais para os particulares. O método auxiliar é o histórico, uma vez que os conteúdos são tratados de modo a situá-los no atual contexto. É dado ênfase ao modelo de pesquisa qualitativa, pois se busca entender a natureza das ações, sem eximir-se do modelo descritivo, quando necessário.

No primeiro item, busca-se apresentar como os conceitos de Estado e democracia estão relacionados com a liberdade de expressão e com a participação popular. A seguir, aborda-se a liberdade de expressão, suas classificações, críticas e o posicionamento no cenário jurídico brasileiro. O direito à informação é o próximo tópico. Nele, são elencadas as suas principais características, bem como sua conexão o Estado e sociedade. Passa-se então para a análise das redes sociais na internet como espaço de debate público. Por fim, apresenta-se a desinformação e seu enlace com os temas precedentes.

\section{ESTADO E DEMOCRACIA}

O Estado democrático moderno tem sua origem nas revoluções dos séculos XVII e XVIII, quando a burguesia adquire força econômica e passa a reivindicar mais autonomia ante o poder soberano absoluto. A Revolução Inglesa, a Revolução Americana e a Revolução Francesa são as expressões máximas desse período.

Para Comparato (2001), nesse momento histórico, o valor de direito como liberdade passou a ocupar o centro da discussão filosófica, em contraposição ao antigo Estado 
absolutista. Na visão de Bobbio (2004, p. 112), a liberdade pessoal antecede o reconhecimento das liberdades civis e políticas, pois é o "primeiro dos direitos a ser reclamados pelos súditos de um Estado."

Assim, a democracia foi construída com a linguagem da liberdade, com os anseios da nova burguesia (AMORIM e GUIMARÃES, 2013). Consoante lição de Dallari (2007), sumariamente, os princípios sobre os quais se fundam o Estado democrático são a preservação da liberdade, igualdade de direitos e, de modo central, a participação popular, uma vez que o regime é orientado para a supremacia da vontade do povo nas decisões políticas. Então, é preciso que essa vontade seja livremente formada e livremente externada. Para o autor (2007, p. 310), esse ponto é primordial, pois é necessário que o Estado capte a vontade autêntica do povo, "que os mecanismos de aferição da vontade popular não deem margem à influência de fatores criados artificialmente."

Os espaços públicos modernos - como local de crítica e reflexão da sociedade surgiram em Londres, no século XVIII (VESTING, 2018). Esses espaços de debate seriam depois trabalhados sob o conceito de esfera pública, cujo resultado articulado é a formação da opinião pública, como aponta Lubenow (2007). O autor (2007) ainda afirma que, embora oriunda dos debates literários, a esfera pública paulatinamente assume papel político, intermediando as relações tensionais entre sociedade e Estado.

Habermas dedicou extensa obra ao estudo da esfera pública e seu papel na sociedade e no Estado. Lubenow (2007) observa que o trabalho de Habermas é voltado para entender as condições de comunicação das quais é capaz de emergir uma vontade política, uma formação de discurso de opinião. Diante da influência dos meios de comunicação de massa, com aprimoradas técnicas de convencimento, Habermas afirmou que a esfera pública não mais existia, mas sim que passou a ser fabricada (ABRUSIO e MEDEIROS, 2020).

Deste modo, é evidente a importância da participação do povo nos Estados democráticos, haja vista fundar-se no conceito de soberania popular. A opinião pública deve influenciar as decisões políticas, mas a sua formação, enquanto elemento social, depende da manifestação individual. Assim, passa-se ao título da liberdade expressão, partindo-se de uma abordagem individual até sua importância social, política e histórica.

\section{LIBERDADE DE EXPRESSÃO}


Neste tópico expõe-se brevemente os elementos da liberdade de expressão, suas vertentes doutrinárias e abordagens contemporâneas. Comparato (2001) ressalta que a liberdade de expressão foi garantida com absoluta prioridade histórica na Declaração de Direitos da Virgínia, em 1776. A Constituição francesa de 1793 também garantiu o direito de manifestação do pensamento.

A liberdade de expressão é fundamental para a construção e aperfeiçoamento do Estado democrático. Destacam-se duas correntes doutrinárias que estabelecem a liberdade de expressão no contexto democrático. Sumariamente, podem ser descritas, uma como visão instrumental e outra como visão constitutiva. Na doutrina norte-americana são conhecidas como teoria democrática e teoria libertária, respectivamente.

A visão instrumental defende que a liberdade de expressão deve formar um debate público rico e plural, o que contribui para a sociedade, pois melhora as condições das informações disponíveis (GROSS, 2020). Com melhores informações, a sociedade pode tomar melhores decisões. Logo, a liberdade de expressão é um instrumento pelo qual se pode melhorar o Estado. Como na teoria democrática, o enfoque está mais no receptor do que no emissor da informação, por isso a circulação das ideias deve ser protegida e regulada pelo Estado, conforme observam Binenbojm e Pereira Neto (2005).

O pensamento de John Stuart Mill exerce influência sobre essa doutrina. O autor aponta que a busca pela verdade é um dos principais benefícios que a liberdade de expressão traz para o Estado. Para Mill, consoante Gross (2020), os debates auxiliam no esclarecimento, já que a discussão força a busca por melhores argumentos. Nesse sentido, até a falsidade teria importância, na medida em que estimula a busca por razões para combatê-la.

De outra banda, aqueles que percebem a liberdade de expressão como valor constitutivo na democracia enfatizam-na como direito individual, isto é, a pessoa deve ter o direito de se expressar e defender publicamente sua visão no debate público (GROSS, 2020). A primazia da teoria libertária é a defesa da autonomia privada, de modo que o Estado deve apenas garantir o direito do emissor, sem interferir ou regular sua manifestação, consoante afirmam Binenbojm e Pereira Neto (2005). Portanto, a liberdade de expressão é vista sobretudo como um direito de defesa.

Os críticos da visão instrumental afirmam que condicionar a participação das pessoas à melhoria do debate pode criar embargos àqueles que não dispõe de muito conhecimento para suspostamente enriquecer a discussão (GROSS, 2020). Nessa toada, Binenbojm e Pereira 
Neto (2005) observam que o Estado se aproxima muito da censura ao qualificar o discurso para avaliar o que merece ou não ser dito. Ainda, consoante Amorim e Guimarães (2013), o conjunto da teoria poderia se encaminhar para um certo elitismo democrático, no qual só os privilegiados podem acrescentar ao debate.

Em contrapartida, Binenbojm e Pereira Neto (2005) ressaltam que a visão constitutiva pode enfrentar críticas ao defender a liberdade de expressão como valor quase absoluto, já que nem todos têm as mesmas possibilidades de manifestação, o que faz com que alguns discursos tenham muito mais relevo social que outros. Isso pode levar ao que Fiss (2005, p. 58) chama de "efeito silenciador do discurso". Outra crítica, aduzida por Amorim e Guimarães (2013), acentua que o ângulo excessivamente individualista pode levar ao esvaziamento do sentido público de liberdade expressão.

Entretanto, Fiss (2005) analisa que a corrente libertária de viés individualista domina o pensamento norte-americano nas últimas décadas. Porém, assevera que muitos adeptos dessa concepção já percebem dificuldades na garantia quase absoluta da liberdade de expressão em detrimento de outros direitos fundamentais. Nesse sentido, Marmelstein (2010) lembra que a liberdade de expressão envolve casos clássicos de conflito de direitos fundamentais.

A celeuma tem relevo pois está em pauta uma possível mudança na forma de perceber o papel do Estado diante da liberdade de expressão. A tradição neoliberal norte-americana formada nas últimas décadas é forte a ponto de a Suprema Corte entender que há praticamente presunção de inconstitucionalidade em qualquer lei que tenda a regular a liberdade de expressão, conforme anotam Binenbojm e Pereira Neto (2005).

Isso se deve, em parte, porque ao longo da história o Estado foi visto como inimigo da liberdade de expressão (FISS, 2005). Para o autor (2005), esse conceito pode ser revisto, na medida em que o Estado atue para proteger os interesses da audiência e os direitos fundamentais. Todavia, assevera que não se trata de arbitrar os discursos, tampouco favorecer qualquer parte, mas sim garantir precondições essenciais de debate.

Importa a exposição da doutrina norte-americana pois, como lembram Binenbojm e Pereira Neto (2005), ela exerce grande influência no Brasil, que após a Constituição de 1988 passou a perceber a liberdade de expressão sobretudo como direito de autonomia individual. Porém, como ressalta Macedo Júnior (2018), ao longo da história, o Brasil não formou uma tradição na garantia da liberdade de expressão. 
Ao contrário, sobressaem-se momentos de extremo cerceamento, dos quais destaca-se, por exemplo, o período que seguiu a Proclamação da República (1889), que foi marcado pela força e pela repressão, como assinalam Schwarcs e Starling (2018). No Estado Novo (19371945) estabeleceu-se a censura em praticamente todos os ramos sociais e artísticos do país. Após o golpe militar de 1964, a liberdade de expressão foi muito reprimida: indiretamente pelos Atos Institucionais, e explicitamente com a chamada Lei da Censura - Decreto-Lei 1.077/1970, que tornou a manifestação do pensamento praticamente inexequível no Brasil (SCHWARCS; STARLING, 2018).

Nota-se, portanto, que as maiores restrições estão ligadas a períodos ditatoriais. Forma-se a seguinte situação: quanto mais liberdade tem o indivíduo, mais democrático será Estado, e no sentido oposto, quanto mais democrático for o Estado, mais liberdade terá o indivíduo. Há uma relação de interdependência, ambos se fortalecem e se complementam.

Ao longo da história, a liberdade de expressão foi majoritariamente discutida sob a ótica da eficácia vertical dos direitos fundamentais. Mas não menos importante é a sua percepção na eficácia horizontal. Nesse sentido, Lima (2012) lembra que não é somente ao Estado que se pode atribuir as ameaças à manifestação do pensamento, pois ele não é o único censor, e muitas vezes nem o mais importante. A maneira como se distribuem os meios de comunicação e a ação de certos grupos econômicos ou sociais também oferecem riscos à expressão. Fiss (2005) afirma que o discurso do ódio tem o efeito de silenciar ou desacreditar discursos considerados minoritários. Amorim e Guimarães (2013) sustentam que a orientação predominantemente econômica dos meios de comunicação forma assimetrias que inibem ou dificultam a expressão do cidadão.

Em face disso, a corrente libertária sustenta que a solução está em aumentar a quantidade de discursos. Mais discursos são a base do melhor debate. Entretanto, a corrente democrática rebate que, no contexto libertarianista, essa tese soa vazia (FISS, 2005). No debate público, não tem sustentação histórica a justificativa de que os discursos contrários aos direitos fundamentais serão vencidos por um argumento melhor, vide os regimes totalitários do século XX (AMORIM; GUIMARÃES, 2013). Aumentar a quantidade de discursos não é garantia de que o melhor irá preponderar.

No cenário brasileiro, os direitos de manifestação do pensamento estão consignados na Constituição Federal de 1988, artigo 5, inciso IV: "é livre a manifestação do pensamento, sendo vedado o anonimato", e no inciso IX: "é livre a expressão da atividade intelectual, 
artística, científica e de comunicação, independentemente de censura ou licença”. Além disso, a censura é expressamente vedada pelo artigo 220, §2 . (BRASIL, 1988)

O Supremo Tribunal Federal (STF) tem adotado uma postura mais afinada aos princípios libertários norte-americanos, como se percebeu no julgamento da Arguição de Descumprimento de Direito Fundamental 130 - sobre a Lei $\mathrm{n}^{\circ} 5.250$ - a chamada Lei de Imprensa. Não foi diferente no Recurso Extraordinário 511.961 - sobre a exigência de diploma de curso superior para exercício da profissão de jornalista.

Portanto, a liberdade de expressão pode ser percebida de diferentes maneiras. Seja pelo viés do emissor, como um direito de defesa, ou do receptor, no sentido de formar um debate público rico e plural. Essa discussão é pertinente pois influi na forma que o Estado se posiciona em face desse direito fundamental. É a liberdade de expressão que garante a participação do indivíduo na formação da opinião pública, e esta, como se evidenciou, deve formar a vontade política do Estado. A essa discussão é necessário concatenar-se o direito à informação, o que será feita no próximo item.

\section{DIREITO À INFORMAÇÃO}

A seguir aborda-se o direito à informação. Busca-se trazer um conceito, suas características, bem como sua relevância para o Estado de direito e para a sociedade contemporânea, compreendendo-o como conexo aos direitos de liberdade de expressão e comunicação.

O direito à informação pode significar mais de um instituto jurídico constitucional, como acesso à informação de órgãos públicos, artigo $5^{\circ}$, inciso XXXIII, princípio da publicidade, artigo 37, caput, ou sigilo de informações, artigo $5^{\circ}$, inciso XII. Pertinente ao tema, tem-se o direito à informação como garantia do livre fluxo de informações na sociedade, consignado no artigo $5^{\circ}$, inciso XIV, da Constituição. Esse direito é proximamente ligado à livre manifestação do pensamento - artigo $5^{\circ}$, inciso IV - e à comunicação social artigo 220 e seguintes. (BRASIL, 1988)

A informação tem como objeto mediato todo conhecimento que possa interessar à coletividade, envolvendo tanto o emissor quanto o receptor, em posição de reciprocidade, conforme aponta Ferreira (1997). Assim, o direito à informação não objetiva a proteção da liberdade de manifestação do pensamento enquanto um direito individual, mas sim como um 
direito coletivo, visando à participação popular nas atividades do Estado por meio da opinião pública, assinala Stroppa (2010).

Sob o ponto de vista liberal, a circulação de informação depende apenas de uma abstenção do Estado. Contudo, na hipótese de não haver a concretização do direito, o Estado deve adotar uma postura ativa a fim de garantir o livre fluxo comunicacional (STROPPA, 2010).

O direito à informação, conforme leciona Nunes Júnior (2011), pode ser decomposto em três variáveis: informar, se informar e ser informado. Informar é o direito conferido às pessoas para que veiculem informações; se informar é o que possibilita a busca por informações; já o terceiro - ser informado - é, efetivamente, haver informações disponíveis para a sociedade. Stroppa (2010) afirma que, embora a última variável não esteja positivada no ordenamento, pode-se percebê-la pela interpretação sistemática da Constituição.

Ademais, Cruvinel (2020) aborda interessante aspecto sobre a informação: os custos. Do ponto de vista do receptor, há o custo financeiro, isto é, o valor que se paga pela informação de qualidade; considera-se que nem todos têm condições ou julgam importante despender dinheiro à informação. Também há o custo de tempo, ou seja, para que a informação seja absorvida é necessário que se dedique certo tempo; considerando que informações mais complexas demandam mais tempo e concentração, muitas vezes apela-se somente às mais breves; e, por fim, o custo cognitivo: a capacidade de compreender o conteúdo da informação, o que envolve a formação cultural, intelectual e a experiência de vida do interlocutor.

Já pelo lado do emissor, Cruvinel (2020) aponta o custo financeiro que se tem para fazer a informação chegar até o receptor, ou seja, o recurso econômico que se emprega no veículo; também há o custo para a produção da informação, isto é, a recompensa ao seu autor pelo trabalho empenhado. Nesse diapasão, observa-se que a desinformação veiculada na internet prescinde da maioria desses custos.

Assim, Ferreira (1997) considera o direito à informação um dos mais preciosos e indispensáveis para o ser humano e, uma vez que é pressuposto para os demais, entende-o como um direito fundamentalíssimo. Stroppa (2010, p. 74) afirma que "a ausência de informação compromete não apenas a liberdade de escolha, senão mina a própria dignidade, bem como o regime democrático". Por conseguinte, precisa-se assegurar ao povo o constante 
acesso à informação, imperioso para possibilitar a sua contínua participação na atividade do Estado. A opinião consciente é formada a partir da informação.

Nesse sentido, Ferreira (1997) observa que a democracia requer discussão, debate e oposição de ideias. Só há democracia com participação, e só há participação com informação. Assim, a qualidade da democracia depende de oportunidades informacionais equitativas. Portanto, é necessário que se oportunize o direito à informação nos seus três níveis, de informar, se informar e ser informado.

Atualmente, as redes sociais na internet dão possibilidades de liberdade de expressão e representam grande espaço de circulação de informações. É o que será abordado no item seguinte.

\section{REDES SOCIAIS COMO ESPAÇOS DE DEBATE PÚBLICO}

Pretende-se apresentar as redes sociais na internet como novos espaços de debate público. Busca-se demonstrar sua crescente importância na sociedade e no Estado. Observamse as novas possibilidades criadas pela popularização do uso das redes sociais, perpassando pelas teorias do ciberespaço, cibercultura e sociedade em rede. Culmina-se com o papel das redes sociais na propagação da desinformação.

Estudo da Organização das Nações Unidas (2019) aponta que mais 4 bilhões de pessoas estão conectadas à internet. As redes sociais somam cerca de 3,5 bilhões de pessoas, conforme Global Digital Report (2019). No Brasil, são 134 milhões com acesso à internet, dados do Cetic.br (2020). Para levantamento da Global Digital Report (2019), do total da população brasileira, $66 \%$ possui cadastro ativo em alguma rede social. Nota-se a grande adesão da população às redes.

Pesquisa do DataSenado (2019) revela que as fontes de informação mais utilizadas pelos brasileiros são, em ordem decrescente: WhatsApp, televisão, YouTube, Facebook, sites de notícias, Instagram, rádio, jornal impresso e Twitter. Desse modo, percebe-se a crescente importância das redes sociais como ferramenta comunicacional, não só no âmbito privado, mas também no consumo de informação.

Considera-se que nos últimos dois séculos o debate público foi pautado pelos veículos de comunicação de massa, baseado em um modelo de sociedade das organizações. Esse sistema conta com filtros hierárquicos de revisão de conteúdo, edição e delimitação de espaço, 
entre outros standards jornalísticos, conforme acentuam Abboud e Campos (2018). Esses filtros, editoriais ou comerciais, conhecidos como gatekeeping, se, por um lado, pretendem dar qualidade às informações, por outro, retiram autonomia das pessoas para difundir conteúdo sem intermediação. Isso está ligado ao modelo de dispositivo comunicacional umtodos (LÉVY, 2010). Um emite e os demais apenas recebem.

No entanto, como assinalam Maranhão e Campos (2018), além de perder valor, esse sistema passou a sofrer grandes dificuldades com o advento e difusão das redes sociais na internet. O novo sistema é descentralizado e não possui os filtros do antigo. Agora cada pessoa é um produtor de conteúdo em potencial, a partir das possibilidades trazidas pela internet. Aqui o sistema comunicacional é todos-todos, ou seja, o fluxo comunicacional é bem mais intenso e recíproco (LÉVY, 2010). Abboud e Campos (2018) assinalam que é essencial entender essas transformações para compreender o fenômeno da desinformação atualmente.

Nesse sentido, Macedo Júnior (2018) acentua que a internet possui um potencial libertador muito grande ao garantir meios para a liberdade de expressão e circulação de informações. $\mathrm{O}$ baixo custo, a praticidade dos equipamentos e a facilidade operacional dos aplicativos em muito contribuem para esse quadro.

Constitui-se o que Lévy (2010) chama de ciberespaço, uma nova forma de ligação entre as pessoas, fruto de um movimento social surgido da internet. Além da estrutura física material, o termo também se refere à grande quantidade de informações ali disponíveis. Do ciberespaço se desenvolve a cibercultura. Para Lévy (2010), a expressão significa o conjunto de práticas e valores desenvolvidos no ciberespaço e baseia-se em três pontos fundamentais: interconexão, criação de comunidades virtuais e inteligência coletiva. Esta última funcionando como resultado da criação de uma sinergia entre os saberes, fruto dos laços criados pelo ciberespaço e do surgimento de comunidades virtuais.

Ainda, Castells caracteriza a sociedade atual como sociedade em rede. O autor (2006) considera que o modelo de redes não é recente na história, porém a tecnologia permitiu que as redes atuais ultrapassassem os domínios do mundo privado e atingissem setores que antes eram marcados por relações verticais. A comunicação digital é essencial para essa mudança. Castells (2006, p. 20), resumidamente, conceitua sociedade em rede como uma "estrutura social baseada em redes operadas por tecnologias de comunicação e informação fundamentadas na microelectrónica e em redes digitais de computadores que geram, processam e distribuem informação [...]". Um sistema com diferentes pontos interligados. 
A comunicação social é um ponto central na ideia de sociedade em rede. Castells (2006) aponta que a comunicação digital não possui organização central, não depende de governos ou das mídias tradicionais, e possui um viés horizontal porque é formada a partir indivíduos, sem intermediação hierárquica. Portanto, a sociedade em rede possui um sistema de comunicação muito diverso da sociedade industrial, mas ainda assim persistem certas características, como a dominação oligopolista (CASTELLS, 2006). O que antes era território das mídias de massa, hoje pertence às plataformas de redes sociais.

Assim, as redes sociais vêm assumindo o papel da esfera pública contemporânea. Conforme aponta Ladeur (2018), juntamente com os veículos de comunicação, a esfera pública plural constitui uma ligação entre a sociedade e o Estado. É o espaço para o debate público. Conforme dados supracitados, a importância da rede social, nesse aspecto, é cada vez maior.

As empresas proprietárias das redes sociais acabam tendo considerável domínio sobre o debate público. Facebook, WhatsApp, Twitter e Google, possuem, sob certa ótica, mais poder que Estados soberanos, pela grande capacidade que têm de interferir nos debates, no fornecimento de informação e na liberdade de expressão, exercendo o controle sobre "os espaços públicos de propriedade privada”, conforme aponta Macedo Júnior (2018, p. 135).

Consoante, ao assumirem o controle do fluxo de informação no debate público, as redes sociais acabam exercendo verdadeira curadoria sobre os assuntos que os usuários irão receber, cujo resultado é uma grande desagregação e fragmentação da esfera pública, como observa Vesting (2018). As políticas que dão a algumas publicações mais alcance do que outras nem sempre são transparentes, tampouco consideram fatores como utilidade pública ou interesse social. Isso tem mostrado grande capacidade de interferência na esfera pública.

Importante considerar-se que as receitas das plataformas são oriundas de publicidade. Quanto mais tempo os usuários permanecem on-line, maior o volume de publicidade veiculada. Decorre daí o interesse em exibir conteúdos que despertem sobremaneira a atenção dos usuários - para que permaneçam mais tempo conectados e assim recebam anúncios publicitários. Por isso, nem sempre o que é exibido está de acordo com o interesse democrático (PIRES; PIRES, 2020). Esse critério pode ter um efeito devastador quando tratar de publicações cujas matérias tenham relevância social, política ou econômica.

Com utilização de algoritmos, as redes sociais formam bancos de dados sobre os temas que despertam mais interesse de seus usuários - chamados big data. Com essas informações, a 
rede passa a disponibilizar conteúdos personalizados para atender aos desejos de pessoas e grupos. Os participantes recebem e visualizam cada vez mais publicações semelhantes entre si, formando as chamadas bolhas, ou câmaras de eco.

São grandes os efeitos desse mecanismo na esfera pública, porque em vez receberem conteúdos que possam contrariar seus pontos de vista, o que seria esperado em um modelo ideal de esfera pública, as pessoas recebem cada vez mais informações que reforçam suas ideias (MACEDO JÚNIOR, 2018). Rais e Sales (2020) afirmam que um dos reflexos disso é a polarização de ideias.

Deste modo, as redes sociais acabam por não cumprir o objetivo esperado para o debate público, que é o confronto de ideias para a formação de consensos, e por consequência fortalecem grupos de pessoas que se encontram - em bolhas - com a intenção de apenas confirmarem aquilo que já sabem ou acreditam (NOHARA, 2020). As redes sociais se tornam agradáveis para os usuários, uma vez que ofertam conteúdos personalizados e aproximam pessoas de gostos similares.

Esse panorama está relacionado ao conceito de pós-verdade, eleita a palavra do ano pelo dicionário Oxford, em 2016. O verbete tem significado de circunstâncias nas quais os fatos objetivos importam menos que emoções pessoais na influência da opinião pública. D’Ancona (2018) analisa que na internet as pessoas recebem continuamente muitas informações e desistem de verificar qual é a verdadeira, então escolhem a versão que lhes dá mais segurança.

Nesse sentido, Ribeiro (2020) avalia que amiúde a desinformação não é reproduzida nas redes sociais simplesmente por má-fé, mas sim porque as pessoas gostariam que aquilo fosse verdadeiro. Ou seja, predominam os fatores emocionais. D’Ancona (2018) lembra que a pós-verdade não está relacionada com a mentira ou com a manipulação, em si, mas principalmente à forma como ela é recebida pela opinião pública.

Assim, nota-se que as redes sociais na internet ocupam relevante papel como esfera pública contemporânea, de modo que a liberdade de expressão e o direito à informação estão proximamente ligados a elas. A comunicação pelas redes sociais garante maior oportunidade de participação, pois não existem os filtros dos meios de comunicação tradicionais.

Entretanto, isso deu enorme poder às empresas proprietárias das redes, porque cabe a elas o controle sobre o fluxo comunicacional. Isto é, nem todos os conteúdos publicados possuem semelhante alcance: a rede privilegia alguns em detrimento de outros. Os critérios 
não são claros. O que mantém as pessoas mais tempo conectadas terá maior visibilidade. $\mathrm{O}$ conteúdo é determinado para cada usuário individualmente. A consequência mais nítida desse processo é a formação de câmaras de eco, as chamadas bolhas. Acrescente-se a isso a hipótese de ser uma informação falsa ou distorcida o conteúdo mais difundido. Esse ponto será abordado no próximo item.

\subsection{DESINFORMAÇÃO}

Neste tópico aborda-se o tema da desinformação. Expõe-se o conceito de desinformação e a preferência deste termo a fake news. Também são elencadas suas principais características e classificações, bem como seus efeitos e seu vínculo com o Estado democrático. Ainda, busca-se demonstrar sua ambígua relação com a liberdade de expressão, além trazer alguns casos recentes que exemplificam sua expressão no contexto atual.

O Seminário Internacional Fake News e Eleições, desenvolvido pelo Tribunal Superior Eleitoral, destacou a inadequação da expressão fake news, já que a tradução literal notícias falsas - não abrange toda a questão. O termo desinformação é considerado mais preciso, pois engloba não só as notícias falsas, mas também as informações verdadeiras utilizadas com o objetivo de enganar, ou aquilo que está entre a "verdade factual e a invenção pura e simples", conforme Zanini (2020, p.67).

Não obstante algumas variações na conceituação de desinformação, a doutrina converge: é a informação criada e divulgada com a intenção de enganar. Conforme aponta Gross (2020), são conteúdos formulados para explorar circunstâncias na internet, para obter vantagens políticas ou econômicas, com formato que procura imitar o jornalismo das mídias tradicionais. Assim, aparentam atender ao critério de objetividade jornalística para obter legitimidade e relevância (CARVALHO, 2020).

A desinformação destaca-se pela apresentação de novidades (RAIS; SALES, 2020), pela utilização de recursos linguísticos associados à sentimentos de raiva, ansiedade e emoções exacerbadas (CASTRO, 2020), e dissemina-se com incrível velocidade (NOHARA, 2020). Por isso, consoante lição de Maranhão e Campos (2018), não se deve atentar apenas para a falsidade dessas informações, mas principalmente para o seu potencial de “enganosidade". Conceitualmente, também é necessário distinguir a desinformação - 
desinformation -, quando há intenção de enganar, do erro jornalístico - misinformation -, quando não há intenção de enganar.

Outrossim, alguns autores apontam que notícias falsas não são um fenômeno recente. No entanto, Macedo Júnior (2020) afirma ser necessário entender que atualmente a desinformação está inserida em um contexto completamente diferente, o que se deve à revolução tecnológica. A facilidade de produção e o baixo custo de divulgação são excepcionais na história. Em muitos casos, a produção é profissional e a divulgação é feita com auxílio de robôs. Desta feita, Barreto Júnior (2020) considera que a tecnologia da informação, associada à desinformação, inaugurou uma nova era de manipulação política.

À vista disso, a desinformação tem chamado a atenção pelos impactos que pode causar nos Estados democráticos. Diante dos eventos recentes na política, Macedo Júnior (2020) assevera que a desinformação mostrou um complexo e perigoso mundo para as democracias, e hoje representa um desafio, sobretudo para as mais vulneráveis, como as latino-americanas. Estudo do Massachusetts Institute of Technology (2018) aponta que, em relação a histórias verdadeiras, notícias falsas têm $70 \%$ a mais de chances de serem retuitadas e levam seis vezes menos tempo para atingir 1.500 pessoas.

Conforme apontam Souza e Teffé (2018), além de minar a confiança nas instituições, a desinformação prejudica a qualidade do debate e compromete o desenvolvimento democrático, uma vez que interfere na capacidade decisória da população. Apesar de não ser fácil identificar com precisão os impactos da desinformação no processo eleitoral, para 34\% dos eleitores brasileiros os meios digitais têm muita influência na tomada de decisão, segundo pesquisa do IBOPE (RAIS; SALES, 2020).

Mas, se a desinformação prejudica o Estado democrático, coibi-la oferece riscos à liberdade de expressão, o que também pode afetar a democracia. Nota-se que em alguns casos a desinformação será nitidamente dolosa - com a manipulação de informações ou imagens hipótese que não desafia a liberdade de expressão. Contudo, em outras ocasiões, poderão ser discutidas ideias ou posições contidas na informação, de modo que não se possa aferir precisamente o que é factual ou especulativo, formando os chamados hard cases (SILVEIRA, 2020).

As últimas eleições nos Estado Unidos, na França e no Brasil evidenciaram-se no cenário político internacional pelo uso da desinformação. Da mesma forma, destacaram-se a saída do Reino Unido da União Europeia, a legislação argentina sobre aborto e a ascensão do 
Movimento 5 Estrelas, na Itália. A desinformação também é aliada de movimentos negacionistas e do discurso do ódio, bem como da deslegitimação da ciência. Blanco (2020) lembra que a Organização Mundial da Saúde considerou a desinformação como uma das principais ameaças à saúde em 2019. É significativa a presença de desinformação no contexto da COVID-19.

Consequentemente, há uma ligação muito forte entre liberdade de expressão, direito à informação, redes sociais e Estado democrático. A liberdade de expressão é exercida nas redes. É ali que as pessoas produzem e recebem informações, formando, de certo modo, uma opinião pública que influencia a condução política do Estado. Porém, essa ferramenta transformou-se em instrumento para a disseminação de desinformação, suscitando questões sobre restrição e colisão de direitos. O fenômeno é relativamente novo, uma vez que foram as alterações tecnológicas dos últimos tempos que criaram esse novo cenário.

\section{CONSIDERAÇÕES FINAIS}

Verifica-se que a pesquisa alcançou todos os objetivos propostos. Neste tópico será feita a análise detida e individualizada de cada um deles. A procura de autonomia individual norteou a construção dos Estados constitucionais modernos. A base dos regimes democráticos é a soberania popular, dando-se grande importância para a vontade do povo, porque é a partir da formação de consensos que devem ser tomadas as decisões políticas do Estado.

O cidadão tem o direito de participar e influir na condução do Estado, não só por meio da escolha de representantes políticos, mas também pelo direito de crítica. Por conseguinte, é essencial que o Estado esteja atento e saiba captar a vontade popular. Nos espaços públicos de discussão são exercidos os direitos de liberdade de expressão e liberdade de informação, de modo a se criar uma opinião pública.

Observou-se que a liberdade de expressão pode ser percebida sob dois aspectos: do emissor e do receptor. Este ponto esclarece as correntes que lideram a celeuma atual sobre o tema. Do ponto de vista do emissor, ele é um direito de defesa, que garante autonomia individual. Da perspectiva do receptor, ele é como um direito coletivo, um instrumento capaz de garantir a pluralidade do discurso, e por consequência, contribuir para o Estado. A depender de qual das percepções se adota, altera-se a forma de compreensão do direito. 
Outrossim, a liberdade de expressão inicialmente foi concebida como um direito fundamental de defesa do cidadão perante o Estado. Por muito tempo a discussão sobre a liberdade de expressão foi pautada pela ótica da eficácia vertical, isto é, pelas restrições impostas pelo Estado. No Brasil, essa questão foi em grande parte superada pelos avanços garantidos na Constituição de 1988, bastante enfática quanto aos direitos de informação e expressão. Nesse ínterim, porém, a capacidade de expressão com maior alcance ficou adstrita ao limitado círculo dos grandes veículos de comunicação de massa.

Com o advento das redes sociais na internet possibilitou-se à grande parte da população oportunidades de expressão sem precedentes, ensejando a participação de um número maior de pessoas na esfera pública. Assim, como se pôde evidenciar, o debate público tem, cada vez mais, migrado para as redes sociais da internet. Contudo, a comunicação nessa mídia possui, em relação aos veículos tradicionais, características inovadoras, como a horizontalidade e a ausência de filtros. Todos são emissores e receptores ao mesmo tempo.

Deste modo, também se alterou o enfoque da análise científica, hoje mais voltada para a eficácia horizontal dos direitos de expressão e de informação, porque, atualmente, não é somente o Estado que tem o poder de restringi-los ou fomentá-los. Com as redes sociais, criaram-se os chamados espaços públicos de propriedade privada. Embora muitos disponham, a priori, da possibilidade de se expressar e de receber informações, nem todos os discursos revelam ter o mesmo poder de alcance. Esse é outro ponto basilar.

Não obstante seja proporcionada a liberdade de expressão, o critério de distribuição dessa informação é definido pela empresa proprietária da rede social. Ou seja, o fluxo comunicacional é controlado pela rede. Isso pode criar uma falsa percepção do debate público, na medida em que, por exemplo, são fornecidas mais informações relacionadas àquelas pelas quais o usuário já tenha demonstrado interesse. Desde modo, são criadas as chamadas bolhas ou câmaras de eco, resultado mais perceptível do enviesamento do debate público. Em face disso, observa-se que sensação de liberdade de expressão e direito à informação, nas redes, é um tanto enganosa.

Nesse contexto, as redes sociais na internet são cenário para disseminação de desinformação. Como demonstrado, pelas suas características, esse conteúdo cativa mais os usuários. Consequentemente, a tendência é que seja mais difundido. Destarte, com auxílio de algoritmos, as redes sociais na internet distribuem os discursos conforme o gosto dos usuários e dominam um importante espaço de ligação entre sociedade e Estado. 
Com efeito, o direito à informação é fundamental para a manutenção dos regimes democráticos. O cidadão precisa de informação para poder atuar com melhor discernimento. A desinformação distorce o debate. A liberdade de expressão pode servir de direito para a difusão de desinformação? A resposta deve ser negativa. Contudo, mais complexa é a questão sobre as formas de controle. Ainda, a desinformação pode viciar o direito de expressão, na medida em que a pessoa, ainda que com boa-fé, manifesta-se a partir de uma desinformação.

Portanto, por meio de um considerável controle da liberdade de expressão e do direito à informação, as empresas de redes sociais na internet pautam o debate público. Esses grupos econômicos não são claros quanto aos critérios utilizados. A desinformação pode ser mais difundida porque atrai os usuários, independentemente do interesse público. Assim, suscita-se o debate sobre quais tendências seguirão as respostas e quais soluções serão dadas ao tema.

\section{REFERÊNCIAS}

ABBOUD, Georges; CAMPOS, Ricardo. A autorregulação regulada como modelo do Direito procederalizado: regulação de redes sociais e proceduralização. In: ABBOUD, Georges; NERY Jr, Nelson; CAMPOS, Ricardo. Fake news e regulação. São Paulo: Thompson Reuters Brasil, 2018. cap. 1, p. 19-39.

ABRUSIO, Juliana; MEDEIROS, Thamara. Fake news - os limites da criminalização da desinformação. In: RAIS, Diogo (coord.). Fake news: a conexão entre a desinformação e o direito. São Paulo: Thompson Reuters Brasil, 2020. cap. 14, p. 243-252.

AMORIM, Ana Paola; GUIMARÃES, Juarez. A corrupção da opinião pública. 1. ed. São Paulo: Boitempo, 2013.

BARRETO JÚNIOR, Irineu Francisco. Fakenews e discurso do ódio: estratégia de guerra permanente em grupos de WhatsApp. In: RAIS, Diogo (coord.). Fake news: a conexão entre a desinformação e o direito. São Paulo: Thompson Reuters Brasil, 2020. cap. 6, p. 113-132.

BINENBOJM, Gustavo; PEREIRA NETO, Caio Mário da Silva. Prefácio. In: FISS, Owen M. A ironia da liberdade de expressão: estado, regulação e diversidade na esfera pública. Tradução: Gustavo Binenbojm; Caio Mário da Silva Pereira Neto. 1. ed. Rio de Janeiro: Renovar, 2005. Título original: The irony of free speech: State, adjustment and diversity in the public sphere.

BLANCO, Patricia. Educação no combate à desinformação. In: RAIS, Diogo (coord.). Fake news: a conexão entre a desinformação e o direito. São Paulo: Thompson Reuters Brasil, 2020. cap. 12, p. 217-226. 
BOBBIO, Norberto. A Era dos direitos. Tradução: Carlos Nelson Coutinho. Rio de Janeiro: Elsevier, 2004. Título Original: L'età dei Diritti.

BRASIL. [Constituição (1988)]. Constituição da República Federativa do Brasil de 1988. Diário Oficial da União: seção 1, Brasília, DF, n. 191-A, p. 1, 5 out. 1988. Legislação Informatizada - Constituição de 1988 - Publicação Original. Disponível em: http://www.planalto.gov.br/ccivil_03/constituicao/constituicao.htm. Acesso em: 20 abr, 2020.

CARVALHO, Lucas Borges de. A democracia frustrada: fake news, política e liberdade de expressão na internet. Internet \& Sociedade, São Paulo, v 1., n. 1 p. 172-199, fev. 2020. Disponível em: https://revista.internetlab.org.br/wpcontent/uploads/2020/02/ilab.01.revista01_0214-Barrastado-2.pdf . Acesso em: 14 jun. 2020.

CASTELLS, Manuel. A sociedade em rede: do conhecimento à política. Tradução: Rita Espanha. In: CASTELLS, Manuel; CARDOSO, Gustavo (coord). A sociedade em rede: do conhecimento à ação política. Lisboa: Imprensa Nacional - Casa da Moeda, 2006. cap. 1, p. 17-30. Disponível em: http://www.academia.edu/download/39508561/REDE.pdf\#page=16. Acesso em: 14 jul 2020.

CASTRO, Leandro Nunes de. Computação e desinformação: tecnologias de detecção de desinformação online. In: RAIS, Diogo (coord.). Fake news: a conexão entre a desinformação e o direito. São Paulo: Thompson Reuters Brasil, 2020. cap. 11, p. 203-216.

CETIC.BR. TIC Domicílios 2019: principais resultados. 2020. Disponível em: https://cetic.br/media/analises/tic_domicilios_2019_coletiva_imprensa.pdf. Acesso em: 10 jul 2020.

COMPARATO, Fábio Konder. A afirmação histórica dos direitos fundamentais. 2.ed. rev. e ampl. São Paulo: Saraiva, 2001.

CRUVINEL, Diogo Mendonça. Fake news e o custo da informação. In: RAIS, Diogo (coord.). Fake news: a conexão entre a desinformação e o direito. São Paulo: Thompson Reuters Brasil, 2020. cap. 9, p. 165-182.

DALLARI, Dalmo de Abreu. Elementos de teoria geral do Estado. 26. ed. São Paulo: Saraiva, 2007.

D’ANCONA, Matthew. Pós-verdade: a nova guerra contra os fatos em tempos de fake news. Tradução: Carlos Szlak. 1. ed. Barueri: Faro Editorial, 2018. Título original: Post-truth: the new war on truth and how to fight back.

DATASENADO. Mais de $\mathbf{8 0 \%}$ dos brasileiros acreditam que redes sociais influenciam muito a opinião das pessoas. 2019. Disponível em:

https://www12.senado.leg.br/institucional/datasenado/publicacaodatasenado?id=mais-de-80dos-brasileiros-acreditam-que-redes-sociais-influenciam-muito-a-opiniao-das-pessoas. Acesso em: 10 abr 2020. 
FERREIRA. Aluízio. Direito à informação, direito à comunicação: direitos fundamentais na constituição brasileira. 1. ed. São Paulo: Celso Bastos Editor, 1997.

FISS, Owen M. A ironia da liberdade de expressão: estado, regulação e diversidade na esfera pública. Tradução: Gustavo Binenbojm; Caio Mário da Silva Pereira Neto. 1. ed. Rio de Janeiro: Renovar, 2005. Título original: The irony of free speech: State, adjustment and diversity in the public sphere.

GROSS, Clarissa Piterman. Fake news e democracia: discutindo o status normativo do falso e a liberdade de expressão. In: RAIS, Diogo (coord.). Fake news: a conexão entre a desinformação e o direito. São Paulo: Thompson Reuters Brasil, 2020. cap. 5, p. 91-112.

LADEUR, Karl-Heinz. Por um novo direito das redes digitais: digitalização como objeto constratual, uso contratual de "meios sociais", proteção de terceiros contra violações a direitos da personalidade por meio de cyber courts. Tradução: Pedro Henrique Ribeiro. In: ABBOUD, Georges; NERY Jr, Nelson; CAMPOS, Ricardo. Fake news e regulação. São Paulo: Thompson Reuters Brasil, 2018. cap. 2, p. 41-58.

LÉVY, Pierre. Cibercultura. Tradução: Carlos Irineu da Costa. 3. ed. São Paulo: Editora 34, 2010. Título original: Cyberculture.

LIMA, Venício A. de. Liberdade de expressão x liberdade de imprensa: direito à comunicação e democracia. 2. ed. rev. e ampl. São Paulo: Publisher Brasil, 2012.

LUBENOW, Jorge Adriano. A categoria de esfera pública em Jürgen Habermas. 2007. Tese (Doutorado em Filosofia) - Universidade Estadual de Campinas, Campinas, 2007. Disponível em: http://repositorio.unicamp.br/handle/REPOSIP/280634. Acesso em: 5 jun. 2020.

MACEDO JÚNIOR, Ronaldo Porto. Fake news e as novas ameaças à liberdade de expressão. In: ABBOUD, Georges; NERY Jr, Nelson; CAMPOS, Ricardo. Fake news e regulação. São Paulo: Thompson Reuters Brasil, 2018. cap. 7, p. 129-146.

MARANHÃO, Juliano; CAMPOS, Ricardo. Fake news e autorregulação regulada das redes sociais no Brasil: fundamentos constitucionais. In: ABBOUD, Georges; NERY Jr, Nelson; CAMPOS, Ricardo. Fake news e regulação. São Paulo: Thompson Reuters Brasil, 2018. cap. 12, p. 217-232.

MARMELSTEIN, George. Curso de direitos fundamentais. 3.ed. São Paulo: Atlas, 2011.

MIT NEWS. Study: On Twitter, false news travels faster than true stories. 2018.

Disponível: https://news.mit.edu/2018/study-twitter-false-news-travels-faster-true-stories0308. Acesso em: 17 mar 2020.

NOHARA, Irene. Desafios da ciberdemocracia diante do fenômeno das fake news: regulação estatal em face dos perigos da desinformação. In: RAIS, Diogo (coord.). Fake news: a conexão entre a desinformação e o direito. São Paulo: Thompson Reuters Brasil, 2020. cap. 4, p. $75-90$. 
NUNES JÚNIOR, Vidal Serrano. Direito e jornalismo. 1. ed. São Paulo: Verbatim, 2011.

ONU NEWS. Estudo da ONU revela que mundo tem abismo digital de gênero. 2019.

Disponível em: https://news.un.org/pt/story/2019/11/1693711. Acesso em: 10 jul 2020.

PIRES, Antonio C. M.; PIRES, Lilian Regina G. M. Desinformação: atuação do Estado, da sociedade civil organizada e dos usuários da internet. In: RAIS, Diogo (coord.). Fake news: a conexão entre a desinformação e o direito. São Paulo: Thompson Reuters Brasil, 2020. cap. 13 , p. 227-242.

RAIS, Diogo. Desinformação no contexto democrático. In: ABBOUD, Georges; NERY Jr, Nelson; CAMPOS, Ricardo. Fake news e regulação. São Paulo: Thompson Reuters Brasil, 2018. cap. 8, p. 147-166.

RAIS, Diogo; SALES, Stela Rocha. Fake news, deepfakes e eleições. In: RAIS, Diogo (coord.). Fake news: a conexão entre a desinformação e o direito. São Paulo: Thompson Reuters Brasil, 2020. cap. 1, p. 25-52.

RIBEIRO, José Horácio Halfeld Rezende Ribeiro. Pinóquio, o grilo falante e as fake news. In: RAIS, Diogo (coord.). Fake news: a conexão entre a desinformação e o direito. São Paulo: Thompson Reuters Brasil, 2020. cap. 19, p. 341-350.

SCHWARCS, Lilia Moritz; STARLING, Heloisa Murgel. Brasil: uma biografia. 2.ed. São Paulo: Companhia das Letras, 2018.

SILVEIRA, Marilda de Paula. As novas tecnologias no processo eleitoral: existe um de ver estatal de combate à desinformação nas eleições? In: ABBOUD, Georges; NERY Jr, Nelson; CAMPOS, Ricardo. Fake news e regulação. São Paulo: Thompson Reuters Brasil, 2018. cap. 11, p. 191-216.

SOUZA, Carlos Affonso; TEFFÉ, Chiara Spadaccini de. Fake news e eleições: identificando e combatendo a desordem informacional. In: ABBOUD, Georges; NERY Jr, Nelson;

CAMPOS, Ricardo. Fake news e regulação. São Paulo: Thompson Reuters Brasil, 2018. cap. 10, p. 177-190.

STROPPA, Tatiana. As dimensões constitucionais do direito de informação e o exercício da liberdade de informação jornalística. 1. ed. Belo Horizonte: Fórum, 2010.

VESTING, Thomas. A mudança da esfera pública pela inteligência artificial. Tradução: Pedro Henrique Ribeiro. In: ABBOUD, Georges; NERY Jr, Nelson; CAMPOS, Ricardo. Fake news e regulação. São Paulo: Thompson Reuters Brasil, 2018. cap. 4, p. 91-108.

WE ARE SOCIAL. Digital In 2019. 2019. Disponível em: https://wearesocial.com/globaldigital-report-2019. Acesso em: 15 mai 2020. 
ZANINI, Fabio. Fake news: como a direita e a esquerda exploram o termo de forma ideológica. In: RAIS, Diogo (coord.). Fake news: a conexão entre a desinformação e o direito. São Paulo: Thompson Reuters Brasil, 2020. cap. 3, p. 65-74. 